\title{
Low BDNF concentrations in schizophrenia may be caused by non-linearity of BDNF correlation with age caused by its interaction with sex
}

\author{
Maja Vilibić ${ }^{1}$, Karolina Novački ${ }^{2}$, Nada Vrkić ${ }^{2,3}$, Dalibor Karlovićc,4 \\ ${ }^{1}$ Department of Psychiatry, University Hospital Center Sestre milosrdnice, Zagreb, Croa- \\ tia, ${ }^{2}$ Department of Medical Biochemistry and Hematology, Faculty of Pharmacy and \\ Biochemistry, University of Zagreb, Zagreb, Croatia, ${ }^{3}$ Department of Clinical Chemistry, \\ University Hospital Center Sestre milosrdnice, Zagreb, Croatia, ${ }^{4}$ Catholic University of \\ Croatia, Zagreb, Croatia
}

\begin{abstract}
Considerable inconsistencies exist between results of the studies on brain-derived neurotrophic factor (BDNF) peripheral concentrations and schizophrenia (SCH). The objective of our study was to check whether these inconsistencies may be explained by confounding effects of age and sex. In this cross-sectional study performed during 2017 at Department of Psychiatry, University Hospital Center Sestre milosrdnice, Zagreb, Croatia, we included a sample of 41 patients diagnosed with $\mathrm{SCH}$. The main outcome was BDNF serum concentrations. We have detected a significant cross-over interaction of sex and age on BDNF concentration $(p=0.017)$. In male patients BNDF concentrations significantly increase with age. In female patients the correlation between age and BDNF was not significant. On this particular sample level, it was negative: aging was associated with the decrease of BDNF concentrations in female patients. BDNF concentrations were significantly different between female and male patients under the age of 22 years (total of $7 \%$ of patients), and above the age of 65 (total of $10 \%$ of patients). BDNF may be a promising schizophrenia biomarker, but different norms should be proposed for the patients of different age and sex.
\end{abstract}

Key words: Brain-derived neurotrophic factor (BDNF), schizophrenia, biomarker, age, sex

Copyright @ 2018 KBCSM, Zagreb

e-mail: alcoholism.kbcsm@gmail.com•www.http://apr.kbcsm.hr

\section{Introduction}

In patients with schizophrenia (SCH), brain-derived neurotrophic factor (BDNF) and nerve growth factor (NGF) concentrations in the cerebrospinal fluid have been reduced since the first psychotic episode [1-3].

\footnotetext{
Correspondence to: Maja Vilibić

Department of Psychiatry, Sestre milosrdnice University Hospital Center, Vinogradska 29, Zagreb, Croatia

Phone: +38591553 7700

E-mail: maja.vilibic@gmail.com
}

Post-mortem studies have demonstrated reduced levels of BDNF mRNA and proteins in the prefrontal cortex [4]. As far as peripheral BDNF concentrations are concerned, previous studies have shown different results depending on the type of biological sample used (serum or plasma), stage of disease, sex, and pharmacotherapy use. Nonetheless, most results are in favor of reduced levels of BDNF in serum of patients with schizophre- 
nia, and some also indicate a clear correlation with negative and catatonic symptoms [5]. Val66Met polymorphism of BDNF gene has its effect also in schizophrenia [6]. Negative influence on protein expression regulates signal transmission, synaptic localization of BDNF and branching dendrites in the hippocampus [7]. Thus, this single nucleotide polymorphism (SNP) is associated with worse neurocognitive function, neuroticism and introversion in patients with schizophrenia [8]. Contrary to most research, Gama et al. reported elevated $\mathrm{BDNF}$ concentration in chronic schizophrenia [9]. The elevated BDNF level can be a sign of clinical improvement, and this is accompanied with the fact that the patients involved in the research have been in a phase of remission and have been suffering from schizophrenia for years. Significant neurodegenerative processes may be more active at the earlier stage of the disease (5-10 years), and such elevated levels of BDNF have been found in advanced longterm schizophrenia or the result of a damaged tissue reaction, or the chronic stage of disease is a period of reduced metabolic aggression towards the brain. Considering this, elevated levels of BDNF may be the result of the progression of schizophrenia or the consequence of long-term therapy with antipsychotics [9]. For the adequate function of neurotrophin, it is not only necessary to increase the level of BDNF but also to adjust the proportion of functional and shortened TrkB receptors [10]. The ratio of these two receptor forms can be a useful indicator of the actual functioning of BDNF. Accordingly, the increase in proportion of functional and reduction in the proportion of shortened, nonfunctional receptor form could be the target of possible future therapeutic agent with the aim of improving BDNF sig- naling in psychotic patients. Patients with increased functional receptor proportion, respond better to antipsychotic therapy [11]. According to the fact that even $50 \%$ of patients with schizophrenia have depressive symptoms, the relationship between serum biomarkers and depressive symptoms in schizophrenia has also been well studied $[12,13]$. Depressive mood in patients with schizophrenia is associated with long periods of hospitalization, poor response to therapy, poor social and cognitive skills, and high relapse frequency [14]. Given that depression and schizophrenia are accompanied with a reduction of $\mathrm{BDNF}$ levels, the assumption was that their co-occurrence would result in even lower levels, but researches showed the opposite. Surprisingly, people with more severe depressive symptoms had higher levels of BDNF. The cause of this was again or chronic progression of the disease stage, or high daily dose of drugs [12]. In conclusion, BDNF could be used as a cognitive deficiency biomarker and as a predictor of clinical prognosis in schizophrenia, but the interpretation of results must take into account the stage of disease, therapy, and other factors affecting its concentration. The objective of our study was to check whether the inconsistencies in studies' findings may be explained by confounding effects of age, sex or treatment with antipsychotics.

\section{Subjects and Methods}

\section{Study design and subjects}

This cross-sectional study was conducted during 2017 at the Department of Psychiatry of University Hospital Center Sestre milosrdnice, Zagreb, Croatia. Ethics Committee of University Hospital Center Sestre milosrd- 
nice approved the study protocol, and we obtained the informed consents from all patients enrolled. The study was conducted in accordance with World Medical Association Declaration of Helsinki 2013 [15].

The targeted population included patients diagnosed with SCH (F20), according to ICD-10 criteria [16]. Inclusion criteria were: confirmed diagnosis of SCH, both sex, age 19 to 80 years, treated in tertiary psychiatric hospital as inpatients. Exclusion criteria were: acute suicide threat, psychoorganic syndrome or mental retardation as schizophrenia comorbidity, and acute intoxication.

We chose a consecutive sample of patients by the order of admission to the hospital. Independent variables were age and sex. These data were obtained from the Hospital medical records.

\section{Serum BDNF determination}

Our outcome was BNDF serum concentration. It was determined by ELISA (EnaymeLinked Immunosorbent Assay) method using the ready-made reagent kit, in which the reaction is based on noncompetitive sandwich principle. Determination of BDNF concentration was performed at the Department of Clinical Chemistry of University Hospital Centre Sestre milosrdnice, using the reagent kit of LifeSpan BioScineces, Inc., USA.

\section{Statistical analysis}

We calculated the needed sample size and power analysis before the beginning of data collection. A sample size of 33 produces a two-sided $80 \%$ confidence interval with a width equal to 0,30 when the estimate of Pearson's product-moment correlation is $r=0,60$. Needed sample size was calculated by PASS 15 Power Analysis and Sample
Size Software (2017). NCSS, LLC. Kaysville, Utah, USA, ncss.com/software/pass.

It was planned in advanced that we will do a sensitivity analysis by repeating the calculation on the file with multiply imputed data if $\geq 5 \%$ were missing. However, this has not happened. Therefore the analysis was done on the cases with complete data only, and the number (proportion) of missing data was reported bellow the tables. In all cases the level of two-tail significance was $\mathrm{p}<0.05$ with confidence intervals on 95\% level. The main analysis of correlation of age with BDNF concentration and moderating effect of sex was performed by Johnson-Neyman technique as it was implemented in Andrew F. Hayes macro PROCESS. Scatter plot with locally weighted regression smoothed trendlines of BDNF on age by sex was plotted in MedCalc Statistical Software version 15.6.1 (MedCalc Software bvba, Ostend, Belgium; https://www.medcalc.org; 2015). Statistical data analysis was performed by NCSS 11 Statistical Software (2016; NCSS, LLC; Kaysville, Utah, USA).

\section{Results}

Total of 61 patients were assessed for eligibility (Figure 1). We finally included 41 patients, (most of whom were markedly ill, $73.2 \%$ ) [17], with the median (IQR) aged 39 (30-58) years. The overall age range was from 19 to 80 years (Table 1 ).

Median (IQR) BDNF concentration was 31 (21-44) $\mathrm{ng} / \mathrm{ml}$, ranging from $4 \mathrm{ng} / \mathrm{ml}$ to $63 \mathrm{ng} / \mathrm{ml}$. We have not found significant nor clinically relevant difference in BDNF concentrations between female and male patients diagnosed with SCH. Crude, unadjusted median (IQR) BDNF concentration was 32 (2145) $\mathrm{ng} / \mathrm{ml}$ in female, and $29(21-45) \mathrm{ng} / \mathrm{ml}$ 
in male patients (Mann-Whitney test, $\mathrm{U}=171$; $Z=-0.31 ; p=0.758)$. Median (95\% CI) BDNF concentration adjusted by quantile regression for age was 33 (27-39) $\mathrm{ng} / \mathrm{ml}$ in female and 32 (24-39) $\mathrm{ng} / \mathrm{ml}$ in male patients $(\mathrm{b}=-1.24$; s.e. $=4.80 ; \mathrm{t}=-0.26 ; \mathrm{p}=0.798)$. Spearman rank correlation between BDNF concentration and age was $\varrho=0.10 ; \mathrm{p}=0.548$.

We have detected the significant crossover interaction of sex and age on the concentrations of BDNF (Table 2, Figure 2). Increase of coefficient of determination of BDNF by the interaction of sex and age was

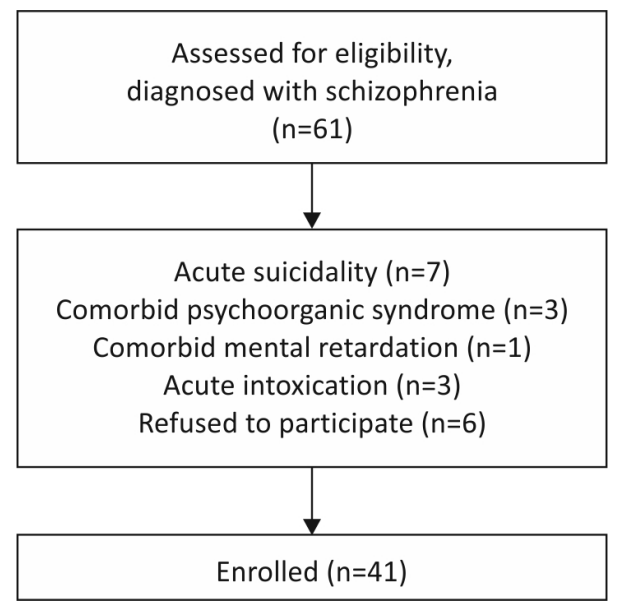

Figure 1. Psychiatric patients study flow

Table 1. Participants sociodemographic and clinical characteristics

\begin{tabular}{lcc}
\hline & $\mathrm{n}$ & $(\%)$ \\
\hline Age (years), median (IQR) & 39 & $(30-58)$ \\
Sex & & $(68.3)$ \\
$\quad$ female & 28 & $(31.7)$ \\
$\quad$ male & 13 & \\
Education & 3 & $(7.3)$ \\
$\quad$ primary & 29 & $(70.7)$ \\
$\quad$ secondary & 9 & $(22.0)$ \\
$\quad$ university & & \\
Age at illness & 27 & $(7-20)$ \\
$\quad$ onset, median (IQR) & & \\
Duration of illness & 12 & $(22.0)$ \\
$\quad$ years), median (IQR) & & $(73.2)$ \\
CGI-S & 9 & $(4.8)$ \\
$\quad$ moderately ill & 30 & \\
$\quad$ markedly ill & 2 & $(19.5)$ \\
$\quad$ severely ill & & $(80.5)$ \\
Treatment with antipsychotics & 8 & $(0.0)$ \\
$1^{\text {st }}$ generation & 33 & \\
$2^{\text {nd }}$ generation & $0.2)$ \\
Antidepressants & 37 & \\
Benzodiazepines & & \\
\hline
\end{tabular}

Data are presented as number (percentage) of participants if not stated otherwise Abbreviation: IQR = interquartile range; CGI-S = Clinical global impression severity scale [17] 
Table 2. Linear regression of BDNF on age and sex

\begin{tabular}{lccrrr}
\hline & $\mathrm{b}$ & $95 \% \mathrm{CI}$ & $\mathrm{se}$ & $\mathrm{t}$ & $\mathrm{p}$ \\
\hline Constant & 41.7 & $(25.8-57.6)$ & 7.86 & 5.31 & $<0.001$ \\
Sex & -31.7 & $(-58.5-4.99)$ & 13.20 & -2.41 & 0.021 \\
Age (years) & -0.20 & $(-0.53-0.13)$ & 0.16 & -1.21 & 0.235 \\
Interaction of sex x age & 0.78 & $(0.15-1.40)$ & 0.31 & 2.50 & 0.017 \\
\hline
\end{tabular}

Abbreviation: $\mathrm{b}=$ regression coefficient; $\mathrm{CI}=$ confidence interval of regression coefficient; se = standard error; $\mathrm{t}=\mathrm{t}$-statistic; $\mathrm{p}=$ statistical significance

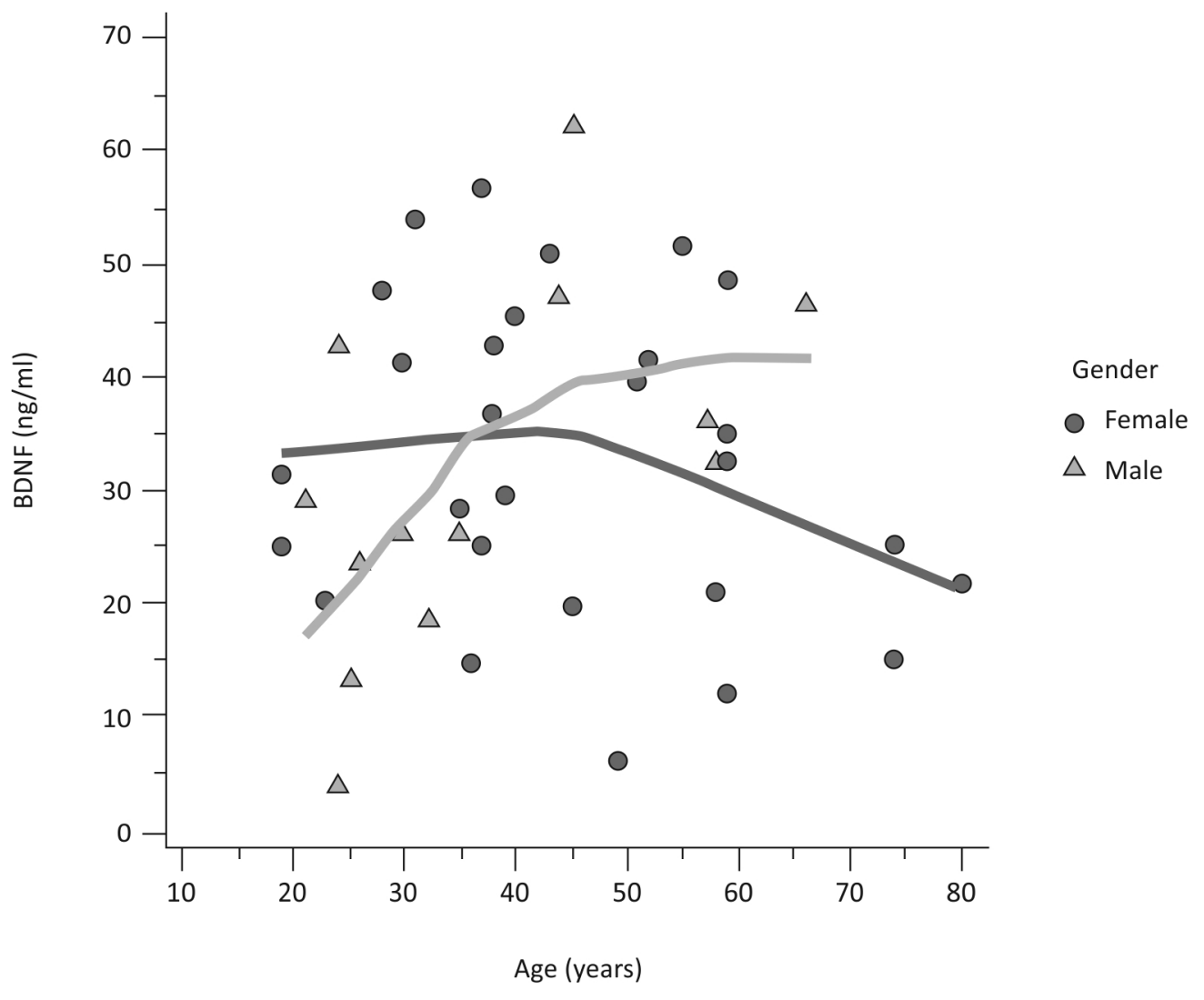

Figure 2. Scatter plot with locally weighted regression smoothed trendlines of BNDF on age by sex ( $n=28$ female, $n=13$ male); degree of smoothing, span $=100 \%$ 
Table 3. Conditional effects of age on BDNF at different sex

\begin{tabular}{lrccrc}
\hline & $\mathrm{b}$ & $95 \% \mathrm{CI}$ & $\mathrm{se}$ & $\mathrm{t}$ & $\mathrm{p}$ \\
\hline Age effect by different sex & & & & & \\
$\quad$ female & -0.20 & $(-0.53-0.13)$ & 0.16 & -1.21 & 0.235 \\
male & 0.58 & $(0.04-1.11)$ & 0.26 & 2.19 & 0.035 \\
\hline
\end{tabular}

Abbreviation: $\mathrm{b}=$ regression coefficient; $\mathrm{CI}=$ confidence interval of regression coefficient; $\mathrm{se}=$ standard error; $\mathrm{t}=\mathrm{t}$-statistic; $\mathrm{p}=$ statistical significance

$\mathrm{R}^{2}=0.14 ; \mathrm{p}=0.017$. Age was significantly correlated with BDNF concentration in male, but not in female patients, and the correlations in two different sexes were of different sign (Table 3). Pearson correlation coefficient between $\mathrm{BDNF}$ concentration and age was $\mathrm{r}=0.55, \mathrm{p}=0.050$ in male, and $\mathrm{r}=-0.23$; $\mathrm{p}=0.239$ in female. Using Jonhson-Neyman technique we found that BDNF concentrations were significantly different between female and male patients bellow the age of 22 years (total of $7 \%$ of patients), and above the age of 65 (total of $10 \%$ of patients) (Table 4).

\section{Discussion}

Our study shows the cross-over interaction of sex and age in BDNF concentration. In male patients BNDF concentrations significantly increased with age. In female patients the correlation between age and BDNF was not significant. On this particular sample level, it was negative: aging was associated with the decrease of BDNF concentrations.

Some previous studies found the sex difference of BDNF levels between ones with and without metabolic syndrome among patients with schizophrenia [18]. In male patients with schizophrenia, those with meta- bolic syndrome had significantly higher serum BDNF levels than those without it. In our study in male patients BDNF concentrations significantly increased with age. Elderly male patients with schizophrenia could have an increased risk or non-diagnosed (not aim of our study) but presented metabolic syndrome and consecutively higher BDNF levels. Also, average dosages of psychopharmaceuticals prescribed to our male patients with schizophrenia were generally somewhat higher than those prescribed to female patients with the same disorder and of the same age, and such practice could partially contribute to the explanation why BDNF concentration significantly increased with age in male patients. Also, it should be reminded that Ikegame et al. found that higher level of methylation at BDNF promoter I was found in patients with schizophrenia compared with controls and particularly the methylation difference was more prominent in male patients [19]. Various, probably complementary and synergistic mechanisms, not uniformly defined yet, could be expected in the basis of found cross-over interaction of sex and age on BDNF concentration.

BDNF serum and plasma reduction was demonstrated in patients with schizophrenia [20], as well as in many other psychiatric and 
Table 4. Conditional effects of sex on BDNF at different ages

\begin{tabular}{|c|c|c|c|c|c|}
\hline & $\mathrm{b}$ & $95 \% \mathrm{CI}$ & se & $\mathrm{t}$ & $\mathrm{p}$ \\
\hline \multicolumn{6}{|c|}{ Age (years) } \\
\hline 19.0 & -17.01 & $(-33.18-0.85)$ & 7.98 & -2.13 & 0.040 \\
\hline 22.0 & -14.70 & $(-29.39-0.00)$ & 7.25 & -2.03 & 0.050 \\
\hline 22.1 & -14.65 & $(-29.32-0.02)$ & 7.24 & -2.02 & 0.050 \\
\hline 25.1 & -12.29 & $(-25.57-0.99)$ & 6.55 & -1.88 & 0.069 \\
\hline 28.2 & -9.92 & $(-21.96-2.12)$ & 5.94 & -1.67 & 0.103 \\
\hline 31.2 & -7.56 & $(-18.55-3.43)$ & 5.43 & -1.39 & 0.172 \\
\hline 34.3 & -5.20 & $(-15.40-5.01)$ & 5.04 & -1.03 & 0.309 \\
\hline 37.3 & -2.83 & $(-12.57-6.91)$ & 4.81 & -0.59 & 0.559 \\
\hline 40.4 & -0.47 & $(-10.11-9.17)$ & 4.76 & -0.10 & 0.922 \\
\hline 43.4 & 1.89 & $(-8.02-11.81)$ & 4.89 & 0.39 & 0.701 \\
\hline 46.5 & 4.26 & $(-6.29-14.80)$ & 5.20 & 0.82 & 0.419 \\
\hline 49.5 & 6.62 & $(-4.84-18.08)$ & 5.66 & 1.17 & 0.249 \\
\hline 52.6 & 8.98 & $(-3.62-21.59)$ & 6.22 & 1.44 & 0.157 \\
\hline 55.6 & 11.35 & $(-2.57-25.27)$ & 6.87 & 1.65 & 0.107 \\
\hline 58.7 & 13.71 & $(-1.65-29.07)$ & 7.58 & 1.81 & 0.079 \\
\hline 61.7 & 16.07 & $(-0.83-32.98)$ & 8.34 & 1.93 & 0.062 \\
\hline 64.8 & 18.44 & $(-0.08-36.95)$ & 9.14 & 2.02 & 0.051 \\
\hline 65.1 & 18.68 & $(0.00-37.37)$ & 9.22 & 2.03 & 0.050 \\
\hline 67.8 & 20.80 & $(0.62-40.98)$ & 9.96 & 2.09 & 0.044 \\
\hline 70.9 & 23.16 & $(1.28-45.05)$ & 10.80 & 2.15 & 0.039 \\
\hline 73.9 & 25.53 & $(1.91-49.15)$ & 11.66 & 2.19 & 0.035 \\
\hline 77.0 & 27.89 & $(2.50-53.28)$ & 12.53 & 2.23 & 0.032 \\
\hline 80.0 & 30.25 & $(3.08-57.43)$ & 13.41 & 2.26 & 0.030 \\
\hline
\end{tabular}

Abbreviation: $\mathrm{b}=$ regression coefficient; $\mathrm{CI}=$ confidence interval of regression coefficient; $\mathrm{se}=$ standard error; $\mathrm{t}=\mathrm{t}$-statistic; $\mathrm{p}=$ statistical significance

neurodegenerative diseases: depression [21]) and is found in both human serum and plasma. Animal studies have demonstrated that stress reduces BDNF expression or activity in the hippocampus and that this reduction can be prevented by treatment with antidepressant drugs. A similar change in BDNF activity occurs in the brain of patients with major depression disorder (MDD, bipolar disorder [22], Huntington's disease [23], Alzheimer's disease [24] and autism [25]. This indicates that the low level of BDNF is not specific to a particular mental disorder, which could limit its use as a specific diagnostic marker. In fact, the serum BDNF concentration could serve as a marker of neuropathological sen- 
sitivity leading to various disorders. Another issue is the question of how much the BDNF concentration in the blood (serum or plasma) reflects the brain concentration. Although BDNF has been shown to cross the bloodbrain barrier with a high-capacity saturating high-capacity transport system in both directions [26] and despite the positive correlation found between serum and cortical levels of BDNF [27], as well as between levels in the blood and the hippocampus [28], it is still unclear to what extent this correlation is correct because the remaining tissues in the periphery are also the source of BDNF. In recent years, BDNF has been found in the peripheral nervous system as well as other organs, such as ovaries, lungs, heart and skeletal muscles [29]. In the blood, BDNF is mostly stored in platelets but is not synthesized there [30,31]. Thus, there is also a difference in BDNF levels in serum and plasma. Serum concentrations are somewhat higher due to release from platelets during clotting. It should be noted that platelets store BDNF from different sources, including nerve and endothelial cells, and thus somehow serve to regulate homeostasis by storing BDNF for release in periods of increased need [30]. BDNF serum levels probably represent an integrated composition from different sources and dynamics in changes in these levels does not have to be closely related to those in the central nervous system [32]. Trajkovska et al.'s research has shown that the concentration of BDNF in full blood is significantly higher in women than in men [33], whereas other studies have not shown significant differences in sex either in plasma or in serum [34-36]. There is a possibility that antipsychotic therapy balances BDNF levels and higher dosages are probably prescribed to patients with more severe symptoms. This is in favor of the higher lev- els of BDNF that have been proven in longterm patients and in those receiving high daily dose of therapy [9,37]. The interpretation of findings from the sample with newly diagnosed SCH is further complicated with the unknown period of undetected psychosis. Like many other molecules in the human body, aging also decreases BDNF levels. Due to the important role of BDNF in brain development and memory, with years learning and memory capacity weakens. Nevertheless, the correlation between age and BDNF concentration was found in this study as in most previous ones.

Further studies on a much larger patients' sample are needed to clarify the preliminary found interaction between age and sex on BDNF levels in patients with schizophrenia.

The first limitation of our study was that we chose a consecutive and not a random sample of patients with schizophrenia. It is possible that patients with particular BDNF concentration have different seasonal patterns of presenting at the psychiatric hospital. We collected the data during spring and early summer and this could induce a sample error. Secondly, we have not collected the data on antipsychotic dosages. Male patients require higher dosages [38]. Higher dosages may be associated with higher BDNF concentrations. If our samples from the population of male and female patients with schizophrenia had different median antipsychotic dosages, the difference in BDNF concentration between female and male patients might have been larger after the adjustment of the dosages confounding effect. Thirdly, we have not collected data on the adherence. If the BDNF concentrations are associated with symptoms severity and pharmacotherapy, then the adherence to the recommended treatment may confound the main results. 
This potential source of bias is most likely low as we did the study on the sample of hospitalized patients. Forth, our results could be biased by the storage of samples. Studies have shown that storage of serum but not full blood at $-20^{\circ} \mathrm{C}$ is associated with significant reduction of BDNF concentration [33]. Unreliability contributes to the fact that, for the purposes of this study, samples were collected over a longer period of time on several occasions. Bus et al. recently identified eight independent factors affecting BDNF concentration: sampling time, sample storage time, pre-sampling food consumption, origin of the patient, age, sex, smoking and alcohol consumption [39].

BDNF may be a promising schizophrenia biomarker, but different norms should be proposed for the patients of different age and sex.

\section{Acknowledgments}

The authors wish to acknowledge the work of all patients, physicians and medical nurses who took part in data collection.

\section{Conflicts of Interest}

There are no conflicts of interest to declare. The study was funded by the research grunt of the

Catholic University of Croatia.

\section{References}

1. Green MJ, Matheson SL, Shepherd A, Weickert CS, Carr VJ. Brain-derived neurotrophic factor levels in schizophrenia: a systematic review with meta-analysis. Mol Psychiatry. 2011;16:960-72.

2. Martinotti G, Di Iorio G, Marini S, Ricci V, De Berardis D, Di Giannantonio M. Nerve growth factor and brain-derived neurotrophic factor concentrations in schizophrenia: a review. J Biol Regul Homeost Agents. 2012;26:347-56.
3. Qin XY, Wu HT, Cao C, Loh YP, Cheng Y. A meta-analysis of peripheral blood nerve growth factor levels in patients with schizophrenia. Mol Psychiatry. 2017;22:1306-12.

4. Reinhart V, Bowe SE, Volfson D, Lewis DA, Kleiman RJ, Lanz TA. Evaluation of TrkB and BDNF transcripts in prefrontal cortex, hippocampus, and striatum from subjects with schizophrenia, bipolar disorder, and major depressive disorder. Neurobiol Dis. 2015;77:220-7.

5. Rizos EN, Rontos I, Laskos E, Arsenis G, Michalopoulou PG, Vasilopoulos D, et al. Investigation of serum BDNF levels in drug-naive patients with schizophrenia. Prog Neuropsychopharmacol Biol Psychiatry. 2008;32:1308-11.

6. Notaras M, Hill R, van den Buuse M. A role for the BDNF gene Val66Met polymorphism in schizophrenia? A comprehensive review. Neurosci Biobehav Rev. 2015;51:15-30.

7. Kuczewski N, Porcher C, Gaiarsa JL. Activity-dependent dendritic secretion of brain-derived neurotrophic factor modulates synaptic plasticity. Eur J Neurosci. 2010;32:1239-44.

8. Galvez-Contreras AY, Campos-Ordonez T, Lopez-Virgen V, Gomez-Plascencia J, Ramos-Zuniga R, Gonzalez-Perez O. Growth factors as clinical biomarkers of prognosis and diagnosis in psychiatric disorders. Cytokine Growth Factor Rev. 2016;32:85-96.

9. Gama CS, Andreazza AC, Kunz M, Berk M, Belmonte-de-Abreu PS, Kapczinski F. Serum levels of brain-derived neurotrophic factor in patients with schizophrenia and bipolar disorder. Neurosci Lett. 2007;420:45-8.

10. Skaper SD. Neurotrophic Factors: An Overview. Methods Mol Biol. 2018;1727:1-17.

11. Martinez-Cengotitabengoa M, MacDowell KS, Alberich S, Diaz FJ, Garcia-Bueno B, RodriguezJimenez R, et al. BDNF and NGF Signalling in Early Phases of Psychosis: Relationship With Inflammation and Response to Antipsychotics After 1 Year. Schizophr Bull. 2016;42:142-51.

12. Noto CS, Gadelha A, Belangero SI, Smith MA, de Aquar BW, Panizzuti B, et al. Association of biomarkers and depressive symptoms in schizophrenia. Nerosci Lett. 2011;505:282-5.

13. Eker SS, Yavasci EO, Cangur S, Kirli S, Sarandol E. Can BDNF and IL-2 be indicators for the di- 
agnosis in schizophrenic patients with depressive symptoms? Acta Neuropsychiatr. 2014;26:291-7.

14. Upthegrove R, Marwaha S, Birchwood M. Depression and Schizophrenia: Cause, Consequence, or Trans-diagnostic Issue? Schizophr Bull. 2017;43:240-44.

15. World Medical Association. World Medical Association Declaration of Helsinki: ethical principles for medical research involving human subjects. JAMA. 2013;310:2191-4.

16. World Health Organsation. ICD-10, International Statistical Classification of Diseases and Health Related Problems, $10^{\text {th }}$ revision, $1^{\text {st }}$ ed. Geneva: World Health Organisation; 1992.

17. Guy W. Early clinical drug evaluation, psychopharmacology research branch. in: ECDEU assessmen manual for psychopharmacology, revised 1976. Rockville: MD - National Institute of Mental Health; 1976. p. 217-22.

18. Chin-Chuen L, Yi-Yung H, Meng-Chang T, Tiao-Lao H. Increased serum brain-derived neurotrophic factor in male schizophrenic patients with metabolic syndrome. Medicine. 2017;96:22(e7089).

19. Ikegame T, Bundo M, Sunaga F, Asai T, Nishimura F, Yoshikawa A, et al. DNA methylation analysis of BDNF gene promoters in peripheral blood cells of schizophrenia patients. Neurosci res. 2013;77:208-14.

20. Ikeda Y, Yahata N, Ito I, Nagano M, Toyota T, Yoshikawa $\mathrm{T}$, et al. Low serum levels of brain-derived neurotrophic factor and epidermal growth factor in patients with chronic schizophrenia. Schizophr Res. 2008;101:58-66.

21. Lee B-H, Kim Y-K. The roles of BDNF in the pathophysiology of major depression and in antidepressant treatment. Psychiatry Investig. 2010;7:231-5.

22. Palomino A, Vallejo-Illarramendi A, GonzálezPinto A, Aldama A, González-Gómez C, Mosquera $\mathrm{F}$, et al. Decreased levels of plasma BDNF in first-episode schizophrenia and bipolar disorder patients. Schizophr Res. 2006;86(1-3):321-2.

23. Ciammola A, Sassone J, Cannella M, Calza S, Poletti B, Frati L, et al. Low brain-derived neurotrophic factor (BDNF) levels in serum of Huntington's disease patients. Am J Med Genet B Neuropsychiatr Genet. 2007;5:574-7.
24. Yasutake C, Kuroda K, Yanagawa T, Okamura T, Yoneda H. Serum BDNF, TNF-alpha and IL-1beta levels in dementia patients: comparison between Alzheimer's disease and vascular dementia. Eur Arch Psychiatry Clin Neurosci. 2006;256:402-6.

25. Hashimoto K, Iwata Y, Nakamura K, Tsujii M, Tsuchiya KJ, Sekine Y, et al. Reduced serum levels of brain-derived neurotrophic factor in adult male patients with autism. Prog Neuropsychopharmacol Biol Psychiatry. 2006;30:1529-31.

26. Pan W, Banks WA, Fasold MB, Bluth J, Kastin AJ. Transport of brain-derived neurotrophic factor across the blood-brain barrier. Neuropharmacology. 1998;37:1553-61.

27. Karege F, Schwald M, Cisse M. Postnatal developmental profile of brain-derived neurotrophic factor in rat brain and platelets. Neurosci Lett. 2002;328:261-4.

28. Klein AB, Williamson R, Santini MA, Clemmensen C, Ettrup A, Rios M, et al. Blood BDNF concentrations reflect brain-tissue BDNF levels across species. Int J Neuropsychopharmacol. 2011;14:347-53.

29. Balkowiec A, Katz DM. Activity-dependent release of endogenous brain-derived neurotrophic factor from primary sensory neurons detected by ELISA in situ. J Neurosci. 2000;20:7417-23.

30. Fujimura H, Altar CA, Chen R, Nakamura T, Nakahashi T, Kambayashi J, et al. Brain-derived neurotrophic factor is stored in human platelets and released by agonist stimulation. Thromb Haemost. 2002;87:728-34.

31. Pliego-Rivero FB, Bayatti N, Giannakoulopoulos X, Glover V, Bradford HF, Stern G, et al. Brainderived neurotrophic factor in human platelets. Biochem Pharmacol. 1997;54:207-9.

32. Sartorius A, Hellweg R, Litzske J, Vogt M, Dormann C, Vollmayr B, et al. Correlations and discrepancies between serum and brain tissue levels of neurotrophins after electroconvulsive treatment in rats. Pharmacopsychiatry. 2009;42:270-6.

33. Trajkovska V, Marcussen AB, Vinberg M, Hartvig P, Aznar S, Knudsen GM. Measurements of brain-derived neurotrophic factor: methodological aspects and demographical data. Brain Res Bull. 2007;73:143-9.

34. Lommatzsch M, Zingler D, Schuhbaeck K, Schloetcke K, Zingler C, Schuff-Werner P, et al. The im- 
pact of age, weight and gender on BDNF levels in human platelets and plasma. Neurobiol Aging. 2005;26:115-23.

35. Kostanjšak L, Zdunić D. The role of thrombocyte serotonin system and some thrombocyte characteristics in treatment of depressive patients with cardiovascular diseases. Alcoholism and Psychiatry Research. 2017;53:33-44

36. Ziegenhorn AA, Schulte-Herbrüggen O, DankerHopfe H, Malbranc M, Hartung H-D, Anders D, et al. Serum neurotrophins--a study on the time course and influencing factors in a large old age sample. Neurobiol Aging. 2007;28:1436-45.
37. Pedrini M, Chendo I, Grande I, Lobato MI, Belmonte-de-Abreu PS, Lersch C, et al. Serum brainderived neurotrophic factor and clozapine daily dose in patients with schizophrenia: a positive correlation. Neurosci Lett. 2011;491:207-10.

38. Lange B, Mueller JK, Leweke FM, Bumb JM. How gender affects the pharmacotherapeutic approach to treating psychosis - a systematic review. Expert Opin Pharmacother. 2017;18:351-62.

39. Bus BA, Molendijk ML, Penninx BJ, Buitelaar JK, Kenis G, Prickaerts J, et al. Determinants of serum brain-derived neurotrophic factor. Psychoneuroendocrinology. 2011;36:228-39.

Sažetak - Rezultati dosadašnjih istraživanja o perifernoj koncentraciji moždanog neurotrofnog čimbenika rasta (engl. brain derived neurotrophic factor, BDNF) u shizofreniji $(\mathrm{SCH})$ su pokazali određene nedosljednosti. Cilj ovog istraživanja bio je istražiti mogu li ove nedosljednosti biti objašnjene konfundirajućim učincima dobi i spola. U ovom presječnom istraživanju, provedenom tijekom 2017 na Klinici za psihijatriju, Kliničkog bolničkog centra Sestre milosrdnice, Zagreb, Hrvatska, uključen je uzorak od 41 bolesnika/ispitanika s dijagnosticiranom SCH. Glavni ishod bile su koncentracije BDNF-a u serumu. Nađena je značajna cross-over interakcija spola i dobi s koncentracijom BDNF-a ( $p=0.017)$. U muških bolesnika/ispitanika, koncentracija BNDF-a je značajno rasla s dobi. U ženskih bolesnica/ispitanica, korelacija između dobi i BDNF-a nije bila značajna. Na razini ovog uzorka, ona je bila negativna: starija dob bila je povezana s nižim koncentracijama BDNF-a u ženskih bolesnica/ispitanica. Koncentracije BDNF-a su se značajno razlikovale između ženskih i muških bolesnika dobi ispod 22 godine (ukupno 7\% bolesnika), i dobi iznad 65 godina (ukupno 10\% bolesnika). BDNF bi mogao biti obećavajući biomarker shizofrenije, ali bi različite norme trebale biti predložene za bolesnike različite dobi i spola.

Ključne riječi: moždani neurotrofni čimbenik rasta (engl. brain derived neurotrophic factor, BDNF), shizofrenija, biomarker, dob, spol 